
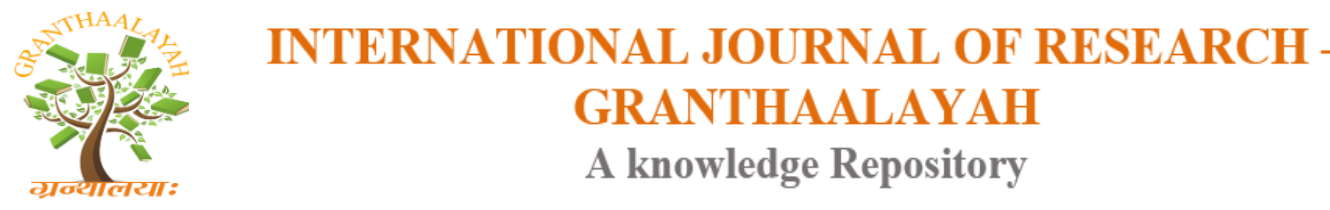

Social

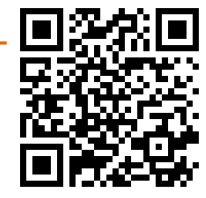

\title{
THE INTEGRATION OF GROUP DISCUSSION METHOD USING AUDIO VISUAL LEARNING MEDIA TOWARD STUDENTS' LEARNING ACHIEVEMENT ON LISTENING
}

\author{
Lamhot Naibaho *1 \\ ${ }^{*}$ Universitas Kristen Indonesia
}

\begin{abstract}
This research is focus on the integration of group discussion method using audio visual learning media. The aim of conducting this research is to find out how the integration of group discussion method using audio visual learning media toward the students learning achievement on listening. The method of the study used was qualitative with Quasy Experimental design. It was done at Teruna Muda Jurnior High School. The instrument used were a set of test and observation sheets. The result of the research are: a) that the everage result using QA method using the audio visual learning is 74; and b) student learning outcomes using the QA method with audio media is no better than the student learning outcomes provided with conventional learning models using audio media. Then it is concluded that the teachers may implement the QA method or conventional learning in teaching listening to the students in the classroom.
\end{abstract}

Keywords: Question and Answer; Audio Visual Learning; Achievement.

Cite This Article: Lamhot Naibaho. (2019). "THE INTEGRATION OF GROUP DISCUSSION METHOD USING AUDIO VISUAL LEARNING MEDIA TOWARD STUDENTS' LEARNING ACHIEVEMENT ON LISTENING." International Journal of Research - Granthaalayah, 7(8), 438-445. https://doi.org/10.29121/granthaalayah.v7.i8.2019.697.

\section{Introduction}

The attention on teaching listening at higher education especially in learning English grows as an important means of receiving communication. The increasing of the importance and usefulness of listening as a subject which is studied through research that is reflected in language skills. Just as listening to people then able to understand an idea which is delivered directly. Through listening, somebody might be a beneficiary, because he/she can develop his/her skill. Being skillful in listening is not automatically gained without learning, but it should be acquiring through a continues training.

Listening is very important for students because the use of language is focused on listening. Although schools have long demanded students to listen extensively, but the direct learning on how best to listen is still forgotten and ignored. Because there is an assumption that said, "it is a 
mere natural ability". Listening is a process of listening to oral symbols with attention, understanding, appreciation, and interpretation to obtain information, capture content, and understand the meaning of communication that has been conveyed by the speaker through speech or spoken language [1]. Listening is a skill to understand the sounds of language that are spoken or read by other people and converted into a form of meaning to continue to be processed, conclusions drawn, and responded to. Listening is a process of connecting what is heard with what students already know about the topic being discussed [2]". Listening is a process for understanding, without judging wrong or right, a statement, so that the facilitator gets the full picture of the message being delivered [3]. So, it can be concluded that listening is a process of listening comprehensively and then understanding the sounds of the language spoken about the topic discussed from what has been heard or a process of hearing, recognizing, and interpreting verbal symbols so that the facilitator gets the full picture of the message delivered.

Listening learning is determined by the student learning activities which will ultimately determine the learning outcomes of the students themselves. Learning outcomes are the emergence of understanding, the emergence of understanding, and the emergence of intelligent responses. Learning outcomes are not only tied to situations of emergence of understanding, but can also be used in other situations. Required activity in learning because in principle learning is doing. Doing to change behavior, so doing activities. Activity is one of the key factors in the construction of knowledge, and participation in all learning activities and interactions every day is the power to access higher information and skills. Learning activities must involve all aspects of psychophysics of students both physically and spiritually, so that the acceleration of changes in behavior can occur quickly, precisely, easily, and correctly, both related to cognitive, affective, and psychomotor aspects [4]. Thus, someone is said to be successful in learning if there is a change in behavior (response). If there is no change in response, there is no learning action.

Students' activities in the classroom can be classified as follows: a) visual activities, which include for example, reading, paying attention to demonstration images, experiments, other people's work; b) oral activities, such as: declaring, formulating, asking, giving advice, issuing opinions, conducting interviews, discussions, interruptions; c) listening activities, for example listening: descriptions, conversations, discussions, music, speeches; d) writing activities, such as writing stories, essays, reports, questionnaires, copying; e) drawing activities, for example: drawing, making graphics, maps, diagrams; f) motor activities, which include among others: conducting experiments, making construction, repairing models, playing, dusting, raising livestock; g) mental activities, for example for example: responding, remembering, solving problems, analyzing, seeing relationships, making decisions; $h$ ) emotional activities, such as being interested, feeling bored, happy, excited, passionate, brave, calm, nervous [5].

So with the classification of activities as described above, it shows that activities in schools are quite complex and varied. If various kinds of activities can be created in schools, of course schools will be more dynamic, not boring and truly become the center of maximum learning activities and will even facilitate its role as a center and cultural transformation. But on the contrary this is all a challenge that demands answer from the teachers. Absolute teacher creativity is needed in order to be able to plan all the varied activities. Many problems that we might encounter must be faced in listening activities. Among the many problems is arranging the reader, pretending to be attentive, confusion, premature consideration, making a wrong note, just listening to facts, daydreaming, and 
reacting emotionally in listening. There are even a number of causes that make people not listen namely, people are tired, people are in a hurry, people are in a state of confusion, and thoughts are in chaos.

There are several factors that influence attention, including experience factors, innate factors, attitude factors, motivational factors, and gender factors. There is no denying that audio media can increase the power of seeing someone [6]. Some of the activities that will contribute to enhancing power are listening to the recording of phonograph recordings of the same lessons over and over (including recordings, songs, drama, poetry and speech), and listening to films especially for students such as radio and television. Listening learning will become more interesting if there is learning media, because the use of media can stimulate active participation of students and can focus students' attention. In this study the media used is audio media. Audio media is a learning media to present learning material that can be enjoyed or understood with the sense of the audience [8]. Teachers must be skilled and able to train, foster, and increase student motivation in listening, provide a means of supporting the teaching and learning process, and in using learning media. The ability to listen is needed readiness, both from the teacher and from the students themselves in the implementation of learning. In this case the teacher must also be able to provide learning with methods that can generate student learning activities.

Learning activities are a series of activities or activities consciously carried out by a person that result in changes in students. That learning itself is activity, mental and emotional activity. Learning events in it always contain activities even though the levels are different. How a teacher can activate student learning depends on the teacher's expertise in implementing and managing learning [9]. High levels of activity in learning make students get more meaningful learning outcomes. The learning outcomes referred to in this study are numbers obtained by students who have successfully completed subject concepts in accordance with the minimum score criteria established in accordance with the applicable curriculum. This means that students must achieve satisfactory values to achieve the specified minimum score criteria [10]. The basic problem complained by teachers in class Teruna Muda Junior High School in Cileungsi on learning Bahasa Indonesia, where most of the students have low ability to listen.

This can be proven by the average value obtained by students, which is lower than 70 . This value does not reach the minimum score criteria set by the school, which is 75 . For example, when the teacher reads a folk tale to students then students are told to listen to the story. After the teacher finishes reading the folk tale then the teacher asks the students questions according to the content of the story, but the result is more students are confused and silent to answer and from that students also ask the teacher to repeat reading the folk tale. From the results of observations, the researchers did several things which were factors that caused the low ability to listen to students, especially in listening to folk tale. There are two aspects that are seen first from the students themselves and the second from the teacher.

The causal factors of this problem are that the students tend to listen less seriously, students lack concentration, and are less active in teaching learning activities, this is due to the lack of interest in a story or the reading of a story. While the causes of the low ability to find interesting things about folk tale figures are the lack of teacher creativity in using tools/materials and the selection of learning methods that can help students in improving listening skills. 
The solution that can be offered related to the problem above is the implementation of "Question and Answer (QA)" learning methods. QA was developed to train students to have the ability and skills to ask and answer questions. In this case students are required to train themselves to have the ability to ask and answer questions that will be given by the teacher in terms of listening [11]. The specialty of the QA method is that learning becomes more active, the teacher can know the child's mastery of the material that has been delivered, encourages the child to dare to submit opinions, and the child gets the opportunity either individually or in groups to ask things that have not been understood [12].

QA is an implementation of constructivist learning strategies that place students as subjects in learning. That is, students are able to reconstruct their own knowledge while the teacher is only a facilitator. This method was developed to train students to have the ability and skills to ask and answer questions, because basically the strategy is a modification of the question and answer method and lecture method which is a collaboration using pieces of paper as a medium. The activity of asking and answering is very essential in the pattern of interaction between teacher and students. The activity of asking and answering conducted by teachers and students in the teaching and learning process is able to grow new knowledge in students. The learning strategy of QA is conducted simultaneously between the question and answer method and the lecture method, so that students are not in a blank mind [13]. The lecture method is the basis for students to get prior knowledge.

The steps for implementing the QA method are as follows: a) making pieces of paper twice the number of students; b) asking each student to complete the statements; c) dividing students into groups small 4 or 5 people; d) choosing the questions (card 1) by each group, as well as topics they can explain (paper 2); e) asking each group to read the questions they have selected. if any of the students can answer, are given the opportunity to answer. if no one can answer, the teacher must answer; f) asking each group to deliver what they can explain from paper 2, then ask them to submit it to friends; g) continuing this process in accordance with the time and conditions available; and h) ending learning by submitting a summary and clarification of the students' answers and explanations.

The objectives of QA learning model implementation ara: a) checking students' understanding as a basis for improving the learning process; b) guiding the efforts of students to obtain a cognitive and social skills; c) giving pleasure to students; d) stimulating and improve students' thinking skills; e) motivating students to be involved in interactions; and f) training the ability to express opinions. the advantages of the QA learning model are: a) the atmosphere becomes more active; b) children have the opportunity both individually and in groups to ask questions that have not been understood; c) the teacher can know the child's mastery of the material presented; and d) encourage children to dare to submit their opinions.

\section{Method}

This study was an experimental method-Quasy Experimental with Posttest only control group design $[14 ; 15 ; 16]$. The population in this research is the 8th graders of Teruna Muda Jurnior High School consisting of 2 classes. The sampling technique used non probability sampling techniques. Data collection techniques used was direct observations to see student learning activities using 
observation sheets that are adjusted to the lesson plan. The procedure of conducting this research are as follows: a) the preparation stage; b) the implementation stage, and c) the final stage. In the preparation stage, observations are carried out by looking at the learning carried out in the classroom done by the teacher, preparing the research learning tools in the form of lesson plan about QA learning methods and audio learning media; d) validating the contents of the research instrument, revising the results of the validation, conducting the research instrument trials, analyzing the results of the trial data, calculating the validation and reliability of the results of the test, compiling the post-test and determining the research schedule with the Indonesian language teacher at Teruna Muda Junior High School; dan e) the implementation stage consists of giving treatment to the experimental class by applying the QA learning method through audio media assistance in accordance with the learning steps, when the treatment process takes place, the researcher and the teacher make observations to see student learning activities using observation sheet, students were given a post-test. Then, the final stage of analyzing the data obtained (Posttest) with statistical tests and making conclusions.

\section{Results and Discussion}

The results obtained in this study are the average student learning outcomes using the QA method with audio media is 74 with a standard deviation of 11.11. After being given a post-test on the experimental class namely learning using the QA method with audio media and conventional learning models on the material listening to folk tale, the following data were obtained.

Table 1: Post Test

\begin{tabular}{|l|l|l|}
\hline Group & Standard Deviation & Marginal Average \\
\hline Experimental group & 11.11 & 74 \\
\hline Control group & 21.58 & 66 \\
\hline
\end{tabular}

Based on table 1 above, it is known that the marginal average of student learning outcomes using the QA method with audio media is classified as good and student learning outcomes using conventional learning models with audio media are quite sufficient. This shows that student learning outcomes using the QA method with audio media provide an average learning outcome better than the conventional learning model with audio media. To obtain accurate conclusions, the data is analyzed by using the results difference test. Difference tests are used to find out which results are better, whether student learning outcomes are taught using the QA method with audio media or conventional learning models with audio media. The difference test results were tested using the t test. Before carrying out the t-test, a prerequisite test must be carried out using the normality test using Liliefors and the homogeneity test using the F-test. Summary of the results of the normality test using the Post-test value are as follows: the experimental group obtained $=0.15$ while the control group gained $=0.16$ with both groups are 0.18 . So based on the results of the normality test, it is obtained that the price for each group is not more than. Thus, the decisions taken are accepted for each group. So it can be concluded that each sample comes from a population that has a normal distribution.

Based on the homogeneity test above, $\mathrm{X}_{\text {obs }}^{2}=1.1$ and $\mathrm{X}_{\text {tab }}^{2}=2.1$ were obtained. Because $\mathrm{F}_{\mathrm{obs}}=$ $1.1<\mathrm{F}_{0} 05 ; 21=2.1$ then $\mathrm{H}_{0}$ is accepted. This means that both groups come from a homogeneous population. Based on the post-test value data in the experimental class students and the control 
class were normally distributed and homogeneous. Therefore, the hypothesis test will be carried out using the t-test. After a statistical test was obtained the experimental group and the control group $\mathrm{T}_{\text {count }}$ value of 1.58 and $\mathrm{T}_{\text {tabel }}$ with 40 degrees of freedom of 1.68 . Because $\mathrm{T}_{\text {count }}$ is $1.58<$ $\mathrm{T}_{\text {tabel }} 1.68$, so $\mathrm{H}_{0}$ is accepted with a significance level of $5 \%$ and $\mathrm{H}_{\mathrm{a}}$ is rejected. So the conclusion of student learning outcomes using the QA method with audio media is no better than the student learning outcomes provided with conventional learning models using audio media. The observation sheet is used to determine student activity during learning with the QA method with audio media. The observation sheet used contains several categories of observations on student learning activities that are adjusted to the Lesson Plans. Observations were carried out by the teacher. The number of observed students were 21 persons. Observations were carried out in 2 meetings. The summary of observation results on student learning activities is presented in Table 2.

Table 2: Summary of Observation Results on Student Learning Activities

\begin{tabular}{|l|l|}
\hline & Students' Learning Activities \\
\hline Number of Observation Points & 21 \\
\hline Average Percentage & 72.43 \\
\hline
\end{tabular}

From Table 2, it is known that the average percentage of student activity from the observation aspect was obtained at $72.43 \%$, the results included in the active category. From the data, it can be concluded that the activity of students during learning using the QA method with audio media in the 8th graders of Teruna Muda Jurnior High School is categorized as "active learning".

\section{Discussion}

Student learning outcomes by treating the students using the QA method with audio media amounting to 74 is in "good" category. Besides that, it was also seen from the minimum score criteria, that $75 \%$ of students in the experimental class getting more than minimum score criteria scores which is 75. This is because using the QA method with audio media creates an atmosphere of learning to be active and fun for students, students get a good chance individually or in groups to ask things that have not been understood, the teacher can know the child's mastery of the material presented, and encourage children to dare to submit their opinions [17;18]. Learning using the QA method with audio media, places students as subjects in learning. That is, students are able to reconstruct their own knowledge while the teacher is only a facilitator. The instructor not only provides teaching materials in the form of exercises sheet, but also provides motivation to his students, so that students feel excited and arise in their confidence to study harder and can do positive things according to the type of intelligence they have. The way of learning given to students must be interesting and varied, so that students do not feel bored to receive subject matter [19;20]. A comfortable learning environment can also make the classroom atmosphere conducive. Students can capture the material taught easily because students focus on teacher delivery. Observations on the observation sheet of student activities were carried out using the QA method with audio media in 2 meetings. The treatment is given by the researcher herself and observers of student learning activities was done by one of the teacher of Bahasa Indonesia. Student learning activities obtained are classified as "active" learning and the average percentage is $74 \%$. This is because students get the opportunity both individually and in groups to ask questions that have not been understood and be brave enough to submit their opinions. 


\section{Conclusion}

Based on the results of processing and analysis of research data in general it can be concluded as follows: a) student learning outcomes after the QA method with audio media on listening to folk tale are quite sufficient; b) student learning outcomes after learning models are applied conventional with audio media on material listening to folk tale is quite sufficient; c) learning outcomes of students whose QA method with audio media is no better with student learning outcomes using conventional learning models with audio media on listening to folk tale; d) the activity of class X students as long as the QA method is used with audio media on the material listening to folk tale classified as active.

\section{References}

[1] Woottipung, K. Effect of Using Video Materials in the Teaching of Listening Skills for University Students. International Journal of Linguistics, Vol. 6 (4), 2014.

[2] Kim, H. S. Using Authentic Videos to Improve EFL Students' Listening Comprehension. International Journal of Contents, Vol.11 (4), 2015.

[3] Richards, J. C. Teaching listening and speaking: From theory to practice. New York, NY: Cambridge University Press. 2008.

[4] Naibaho, L. Teachers' Roles on English Language Teaching: A Students Centered Learning Approach. Vol. 7 (4), 2019. pp. 206-212.

[5] Diedrich, P. B. Students' Learning Activities. Retrived from http://binham.wordpress.com/2012/04/24/students-learning-activities. On 27/08/2019.

[6] Cakir, I. The Use of Video as An Audio-Visual Material in Foreign Language Teaching Classroom. The Turkish Online Journal of Educational Technology - TOJET Vol. 5 (4), 2006.

[7] Goncalves, et al. Utilizing Audiovisual Media and Learning Motivation On Student Achievement oyf Social Department Grade VIII Student Fatumeta, Dili. International Research-Based Education Journal, Vol. 1 (1), 2017.

[8] Al-Khayyat, A. S. J. The Impact of Audio-Visual Aids (AVA) and Computerize Materials (CM) on University ESP Students' Progress in English Language. International Journal of Education and Research, Vol. 4 (1). 2016.

[9] Hackathorna, J. Solomon, E. D, Blankmeyer, L. K. Learning by Doing: An Empirical Study of Active Teaching Techniques. The Journal of Effective Teaching, Vol. 11 (2), 2011. Pp. 40-54.

[10] Mathew, R. Collaborative Learning-An Effective Method for Teaching Native Arabic Speakers. Journal of Foreign Language Teaching and Applied Linguistics, 2 (2), 2015.

[11] Al-Darwish, S. The Role of Teacher Questions and the Socratic Method In EFL Classrooms in Kuwait. World Journal of Education, Vol. 2 (4), 2012. Pp. 76-84.

[12] Etemadzadeha, A. Seifi, S. B. Farc, R.H. The role of questioning technique in developing thinking skills: The ongoing effect on writing skill. Procedia - Social and Behavioral Sciences. Vol. 70, 2013. Pp.1024-1031.

[13] Tofade, T. et al. Best Practice Strategies for Effective Use of Questions as a Teaching Tool. American Journal of Pharmaceutical Education 2013; 77 (7), 2014. Pp. 1-9.

[14] Cohen, Louis., Lawrence Manion, \& Keith Morrison. (2007). Research Methods in Education, 6th Edition. New York: Taylor and Francis e-Library.

[15] Creswell, J. Research Design: Qualitative, Quantitative, and Mixed Methods Approaches, 4th Edition. London: SAGE Publications, Inc. 2013.

[16] Creswell, J. Educational Research: Planning, Conducting, and Evaluating Quantitative and Qualitative Research, 4th Edition.

[17] Slavin, R. E. Co-operative learning: what makes group-work work. The nature of learning: Using research to inspire practice, 2010. 161-178. 
[18] Wood, David, Jerome S. Bruner, and Gail Ross. The role of tutoring in problem solving. Journal of Child Psychology and Psychiatry. 17:, 2006. 89-100.

[19] Naibaho, L. The Effectiveness of Scaffolding Method on Students' Speaking Achievement. International Journal of Research-Granthaalayah, Vol. 7 (5), 2019.

[20] Ashaver, D \& Igyuwe. The Use of Audio-. Visual Materials in the Teaching and Learning Processes in Colleges of Education in Benue State-Nigeria. IOSR Journal of Research \& Method in Education (IOSR-JRME), Vol 1 (6), 2013. pp 44-55.

\footnotetext{
*Corresponding author.

E-mail address: lamhot.naibaho@ uki.ac.id
} 